\title{
Competition over jurisdictions and political manoeuvers in Niger
}

\section{Christian Lund}

\section{(2) OpenEdition \\ Journals}

Electronic version

URL: http://journals.openedition.org/apad/1481

DOI: 10.4000/apad.1481

ISSN: 1950-6929

Publisher

LIT Verlag

\section{Printed version}

Date of publication: 1 June 1995

\section{Electronic reference}

Christian Lund, «Competition over jurisdictions and political manoeuvers in Niger », Bulletin de l'APAD

[Online], 9 | 1995, Online since 25 July 2007, connection on 08 September 2020. URL : http:// journals.openedition.org/apad/1481; DOI : https://doi.org/10.4000/apad.1481

This text was automatically generated on 8 September 2020

Bulletin de l'APAD 


\title{
Competition over jurisdictions and political manoeuvers in Niger
}

\author{
Christian Lund
}

Résumé

1 Récemment, le Niger a vécu une transformation politique vers la démocratie et le pluralisme et le remplacement du gouvernement autocratique par un gouvernement démocratique a donné l'espoir que l'Etat sera doté d'une nouvelle légitimité.

2 Néanmoins, la situation économique du pays est pitoyable et les nouveaux politiciens ne sont en mesure ni d'éprouver la croissance économique ni de promouvoir un développement social à court ou moyen terme. Le domaine où le rendement politique est immédiat et plus intéressant est aussi le domaine où la compétition politique pourrait mettre en cause la crédibilité et la légitimité du nouveau système politique ; notamment le domaine des processus juridiques et surtout les litiges fonciers. Depuis 1986, le foncier a été actualisé à travers l'élaboration d'un Code Rural qui vise à transformer les droits fonciers coutumiers en droits fonciers privés. La coïncidence du processus de démocratisation avec l'actualisation du foncier compose le thème de l'article. A travers un nombre d'études de cas détaillées, l'engagement de partis politiques dans le processus juridique est analysé et le risque que cela pose pour la légitimité du nouveau régime est discuté.

Introduction

3 In several African states democracy and political pluralism have been celebrated in the 1990's. In Niger 17 years of military and one-party rule was thus in 1991 replaced by a sovereign National Conference which issued a new constitution operating with multi party democracy. Hopes have been high that a democratic government would replace the autocratic one-party rule and would endow the state with a new legitimacy.

Democracy rests on some degree of accountability and open competition for political support has become omnipresent in public life in Niger. Already since the death of president Kountché in 1987, political debate and competition had grown to become intense. In particular, the confrontation between the MNSD (Mouvement National pour la Société de Développement), representing the old regime, on the one hand, and an 
alliance of parties with CDS (Convention Démocratique et Sociale) as the most prominent one, arguing for "change", on the other hand, has penetrated and shaped the political arena.

5 One of the areas where the immediate political pay off is highest is one where the political competition might put the credibility and legitimacy of the new political system most at risk. It is the area of legal procedures and in particular the legal disputes over land. Land tenure has been highly actualized as a political issue since 1986 with the announcement of a tenure reform whose basic idea has been securing rights in land by transforming traditional rights of tenure into private ownership. The task of overseeing this process has been put into the hands of a new local tenure commission ${ }^{1}$.

6 The conjuncture of democratization, on the one hand, and land tenure as a political issue, on the other hand, is the focus of the present paper.

Democratization, politization and legitimacy

7 The politicization of the legal procedures raises important questions about the correspondence between legitimacy and effective jurisdictions. As Moore (1988: 170) puts it: "In analyzing the legitimacy of a state one must keep distinct at least two aspects : 1) the nature of the claim to legitimacy and 2) the motives of its citizens when they subject to authority," i.e. accept certain jurisdictions.

8 Reinstating a democratic constitution makes legality the overall reference point for the state's legitimacy. This is particularly true for the legal sphere ${ }^{2}$. Legitimacy of state institutions implies a recognition and thus an appreciation of them, and this is intimately linked to the concepts of justice and propriety. Completely opportunistic and situational submission to a state institution and erratic recognition of its jurisdiction can hardly be considered effects of legitimacy. The litmus test of an institution's legitimacy would thus be that its decisions are generally accepted even in spite of them being unfavorable for meeting immediate specific interests.

of course, it would be unreasonable to expect that a military regime should turn into a democratic state over night and thereby endow its institutions, in particular its legal institutions, with a new legitimacy. The question is rather whether the process of democratization seems to be conducive for endowing the legal institutions with increasing legitimacy or not.

10 One of the themes in the democratization process in Niger has long been the question of decentralization. Basically, deconcentration has always been the predominant feature of the government administration set up with Préfets and Sous-Préfets appointed by the government as the representatives of each ministry at the Département and Arrondissement levels respectively. However, the new constitution operates with future democratic assemblies at the Arrondissement level, and the question is how the prospects of devolution to democratic assemblies influence the legitimacy of the legal institutions.

11 In the following I shall outline the Nigerien background for raising these questions. First, the legal system concerned with land tenure and the process which put land tenure high up on the political agenda will be described. Thereafter, I shall sketch out the nature of the political competition at the local level which preceded and led to the democratic competition of the present.

Background Land tenure 

agenda. During the military regime, president Kountché in 1974 declared that the land belonged to the tiller of the soil. It was declared that all land, no matter how it had been acquired and no matter under which tenure rules it was held, should henceforth belong as private property to the person cultivating it. This provoked a number of conflicts between users and owners of the land in which the latter defied the declaration and insisted that a tithe be paid in recognition of their ownership. Many of the conflicts arising from Kountché's declaration were not resolved. In 1977 the government therefore issued a circulaire prohibiting any land tenure dispute resolution by any local authority, governmental or traditional.

This in turn led to a situation of precarious stability. Tithe was often still paid recognizing that the land belonged to the owner and not to the cultivator - a defiance of the Kountché-decree. However, the use right holder stayed on the land.

Since all institutions had been stripped of their competences in land tenure questions by the government, no conflict had a predictable course and none of the institutions operating in the rural areas had formal powers to deal with land conflicts. However, neither conflicts, their sources nor the institutions disappeared, but it all became much more discreet, informal and precarious. Generally, 6 different politico-legal institutions were the targets of the plaintiffs for settlement of conflicts. While all informally involved in dispute processing, each institution had its primary domain. The administrative structure with the Prefet, the Sous-prefet and the Chef de Poste. The traditional structure with the Sultan, the Chef de Canton and the Chef de Village for the sedentary farming communities and the Chef de Groupement and Chef de Tribu for the original pastoralists - now largely sedentarized -communities. The legal structure with the courts. The police with the gendarmerie. And fmally the Kadi who heads the religious structure and interprets the Islamic law.

Figure 1 : institutions dealing with in land conflicts

\begin{tabular}{|l||l||l|l|l|l|}
\hline Adm. & $\begin{array}{l}\text { Traditional } \\
\text { farmers }\end{array}$ & $\begin{array}{l}\text { Traditional } \\
\text { Pastoralists }\end{array}$ & Legal & Police \\
\hline \hline Préfét & Sultan & Chef de Groupe & $\begin{array}{l}\text { Juge de } \\
\text { paix }\end{array}$ & Gendarmerie & Kadi \\
\hline \hline Sous-Préfet & Chef de canton & Chef de tribu & & \\
\hline \hline $\begin{array}{l}\text { Chef de } \\
\text { Poste }\end{array}$ & Chef de village & & & \\
\hline
\end{tabular}
while each institution was organized hierarchically, between them only indirectly a tacit hierarchy existed. Thus, the administrative hierarchy made the Canton chiefs the auxiliary staff of the Sous-Préfet. But complementarity as well as competition between different illicit but effective jurisdictions characterized the legal system.

In 1986 a process of establishing a new land tenure reform -the Rural Code - was undertaken. The reinstatement of land tenure on the political agenda was then 
furthered during the National Conference in 1991. Characteristic of the National Conference was the proposed reversal of almost any law or decree passed during the military regime. All remnants of the old regime were foul and should give way for "change". And although it was not part of the final declaration, it had been voiced - and heard - that now was the time for people to claim the property that they had lent or hired to others and subsequently lost due to the Kountché-decree. As the tenure disputes were no longer illegal, the tacit hierarchy going from the Chef de Village over the Chef de Canton to the Sous-Préfet was now recognized as an official hierarchy for dispute settlements with the Juge de Paix as the final instance if a settlement could not be obtained. Complementarity and competition did, however, not disappear.

Political competition

While social and political struggle are immanent in all societies, overt contestation of government and public political competition are not. During the military regime from 1974 to 1991 only the military's party - MNSD - was authorized to conduct politics. And the regime managed to quell political opposition until the death of president Kountché in 1987.

18 From the late 1980 's, however, a number of organizations began to operate under politically innocent names and programs. One of these, the Association Mutualiste d'Animation Culturelle et Artistique (AMACA), was thus brought into being in 1989 by intellectuals from the country's second city - Zinder. The real objectives were to protect the interests of these predominantly Zinder-Hausa civil servants against the historic Djerma favoritism prevailing in the state apparatus and to favor their region Zinder - in the national development. The modus operandus of this organization quickly became one of mutual help and defense against abuse from the authorities and AMACA recruited extensively among non-intellectuals. Thus, people found in AMACA intellectuals who would assist them when they encountered trouble with government officials or traditional chiefs; with an AMACA-militant by the side, a farmer was less liable to be subjected to the arbitrariness of a gendarme looking for a bribe or Canton chief trying to expropriate their land. Furthermore, if a farmer was arrested with illegally cut wood and had his donkey confiscated by the patrols of the Service de l'Environnement, the leaders of AMACA in Zinder would raise the funds among members to pay the fine. This was facilitated by the membership of wealthy businessmen from Zinder town. They would pay the small fine of 2.000 FCFA and in return get the delinquent out of trouble and receive his loyalty for it. The businessman, on the other hand, could count on AMACA if his truck full of goods from Nigeria was held back at the customs office. In a matter of hours AMACA could mobilize hundreds of militants who would harass the customs officers to release the goods and not report further. This set-up was very dynamic; AMACA delivered what the members needed without being 100 fussy about the legality of its acts.

In 1993 multi party elections were held for the first time in decades and AMACA converted itself into a political party -CDS. During the political campaign prior to the elections, the official CDS slogans were much centered around bringing back justice to the people, fighting government officials' abuse of power etc. During the heat of the campaign, slogans and policy promises were often given an extra twist to become more catchy for the rural electorate : abolition of the traditional chieftaincy, of the forest guards and of taxation, and retrial of all unjust trials made by the MNSD controlled administration and traditional chiefs were tempting promises to make. In particular, it 
was brought forth in the propaganda that land lost due to expropriation or rigged trials conducted by the tradition al chiefs were to be handed back. Though not formally committed to these promises by any official programme, when the CDS won the elections, one of the major issues at the local level was the emerging land tenure disputes. And the promises made by the CDS were largely retained by the rural population.

CDS won the majority in parliament in a coalition with two other parties and subsequently participated in government. In its nomination of Préfets, Sous-Préfets and other important civil servants in the administration, party members were preferred and a tacit quotation system between the coalition parties was established. In the Département of Zinder and the Arrondissement of Mariga the Préfet and the Sous-Préfet put into office were accordingly out of the CDS quota. It is, however, important to stress, that while democratization has brought about intense political competition at the local level, the political and administrative players are accountable to no local democratic institution, since local assemblies are still not established.

The arrival of a very dynamic, delivering and populist party, which contrary to the MNSD, was separable from the state itself in the sense that it drew its legitimacy from attacks on the state, added a competing institutional option for dispute settlement to the range of options already in place as the following cases will demonstrate.

Three cases ${ }^{3}$

I shall present two examples to illustrate the political parties - i.e. the ruling party CDS - insertion in the legal procedures. The cases are elaborate in order to present some of the context and historical sequence that the party intervention is interacting with. A third brief example serves to illustrate the manoeuvering of the Sous-Préfet in a situation where his various capacities elevates him out of bureaucratic control and into an extended discretionary terrain.

The influence of the political parties is exercised in several ways. It ranges from simple brokerage between a plaintiff and some public authority, over conducting hearings and providing settlements under a quasi-formal ritual, to more stealthily activating party members holding key-positions within the administration thus capable of influencing the outcome of legal procedures.

Settlements

24 A land tenure dispute had occurred between Saley and Djibo in a village in the Canton de Gao in 1994. Saley had c1aimed some land back from Djibo who denied that Saley had any such rights. When Saley had first tried to let Djibo be summoned at the Chef de Canton's court for settlement of the dispute, Djibo had managed to pay off the bailiff not to be able to find him. Subsequently the case was postponed and would allow Djibo to cultivate the land, if he managed to plant his crop before the case was reopened.

When the rainy season began, however, both Djibo and Saley began to cultivate; one planting on what the other had planted. Saley went to the Chef de Canton who dismissed him referring to the commenced cropping season and the closure of the land litigation season. Saley then went to the local member of parliament, Yaccouba Mato, to complain. Yaccouba Mato suggested patience and to take up the case next year. Dissatisfied with this advise, Saley went to consult one of the more militant CDS-cadres, Zakari Ousseini, and explained his situation. Zakari Ousseini and an associate of his went with Saley to the village where Djibo was taken by surprise. Zakari Ousseini 
scolded Djibo for not respecting a summons, and then he let both parties present their case. After having heard them, Zakari Ousseini offered Saley to take a Coranic oath which he did. Utterly unprepared for this, Djibo accepted Saley's oath and ceded the field in question to Saley. Later, after having consulted friends and relatives, Djibo mounted enough courage to go to the Chef de Canton to corn plain about the procedure. The Chief dismissed him referring to the cropping season, and suggested that Djibo took up the case with the Sous-Préfet after the harvest.

Several elements in this course of events merit a comment. First, it is obvious that the CDS cadres do not subscribe to a uniform approach towards demands for their intervention. And Zakari Ousseini used the occasion to compete with Yaccouba Mato in rendering justice. He most likely scored a few points against Yaccouba Mato as the committed cadre who could not ignore injustice. Second, the combination of surprise, the authority of the president's party and the use of the Coran and the Coranic oath whose legal validity cannot be disputed without the risk of loosing one's honor, made it virtually impossible for Djibo to oppose the procedure and the result. Third, when the Chef de Canton learnt about the settlement and Zakari Ousseini's and CDS' involvement, he transferred the reopening of the case away from himself, because the chiefs "do not do politics", and directed it towards the Sous-Préfecture.

When discussing the case with Zakari Ousseini, he denied having conducted a legal procedure ; he would, as he said, never do that - he was not an official authority. He had merely witnessed a fanner take an oath, since no other authority [sic !] was willing to assist and endow the ceremony with an official tinge. However, while the procedure was a simulation of an officially recognized legal procedure, it was effective and real enough to make the land change hands. At least for one cropping season.

Discussing the case with the Sous-Préfet, he stated that the incident was not unique : "The formal hierarchy is "burnt" [brûlée/not respected] all the time and the political parties intervene and set themselves up as a parallel justice. It is a non-sense". Nevertheless, he knew about the actual case but had not reacted upon it. He had, as he said, not been informed. By that meaning not informed in a way he could not ignore.

Activating party influence on key positions in the administration

A tenure dispute had come about between Mamane and Idi in a village in the Canton de Gao. Mamane's mother, her sister and their brother Elli. Ali had inherited their father's land some time in the 1930's. Mamane's unde, Elli. Ali, then went on a pilgrimage to Mekka, left the land with his sisters, and never returned.

In 1951 Idi's father and halfbrother to Elh. Ali (same mother) returned from his pilgrimage to Mekka stating that he had met Elli. Ali, and that Elli. Ali had lent him the land he had inherited in the 1930's. Mamane's mother and aunt refused at first, but when Idi's father had them summoned before the Sultan of Zinder and there produced witnesses to his and Elli. Ali's agreement, they ceded the field the him as a loan.

When Idi's father died in 1972, Mamane addressed Idi to daim the field. Idi now refused that the field was only a loan, and a court settlement in Zinder ensued. Here, the same witnesses as in 1951 testified that the field was indeed a loan. A letter stating this was issued, but Idi requested that he could continue the cultivate the land for another year, granting him time to find another field. Mamane conceded to this.

In 1974 a military coup brought Kountché into power. When he first declared that the land belonged to the tiller of the soil, and later in 1977 furthermore prohibited any 
local or traditional authority from dealing with tenure matters, Mamane had to let the case lie - but he was fairly confident since he had the magistrate's letter.

The case erupted again in 1992, when Idi's sister summoned him to the Chef de Canton charging him with keeping some of the family's land out of the division of property following the death of their father. She pointed to the field that Elli. Ali had transferred to their father and requested it be divided among the heirs. Idi was forced to cali Mamane to testify that the field was not his family's property and subsequently should not be distributed among the heirs. But this was a dangerous step. Mamane now used the occasion to claim the land back. Idi objected to this; "he had just saved Mamane's land from expropriation - and was this a way of thanking him". Not able to reach a settlement, the Chef de Canton transferred the dispute to the magistrate in Zinder. Idi now managed to produce a number of postponements, in particular by bringing new aspects into the case. Most important was the claim that while some of the land was indeed a loan, most of what was now claimed by Mamane, used in fact to belong to Elli. Ali's and Idi's father's common mother, and thus not to the sisters of Elh. Ali (Le. Mamane's mother and aunt). The claim was not taken into consideration, and when Moussa Idi requested to take a Coranic oath to back his statement, it was denied him by the magistrate who settled the case by granting Mamane the land. At this point the magistrate issued a preliminary, handwritten court ruling, stating that the land should return to Mamane. Mamane took possession of the land and planted - to be sure -well before the beginning of the rainy season.

Idi was not satisfied with the situation -loosing the land his family had cultivated since the 1950's. As he was one of the village's known CDS supporters, he went to the MP Yaccouba Mato in Mariga to ask for help. Yaccouba Mato would not engage himself since the magistrate had already issued a preliminary ruling, and Idi went to Zakari Ousseini. He, in turn, accompanied Idi to the CDS polit bureau in Zinder where a CDS cadre took him to the Préfet. After having heard him, the Préfet telephoned to the Sous-Préfet in Mariga and urged him to do something. The Préfet suggested that Idi summoned Mamane before the Sous-Préfet, which he did. At the scheduled hearing, the Sous-Préfet told Mamane that the settlement granting him the land was valid for this year only, and that the dispute would be tried again after the harvest. He added this on the magistrate's handwritten court ruling which Mamane kept.

The case is thus still in suspension, and ail await the reopening of the season for land litigation.

The first thing to notice about a case like this is that it dates so far back and contains no written contracts between the opposed parties that simple proof is difficult to produce. While mutually contradictory, neither of the parties' arguments are completely unreasonable or improbable. And the winner is the one given the most accommodating interpretation.

Second, the case had, by the intervention of the magistrate, reached a level of authority which was no match for at simple settlement by a local party cadre as in the previous example. It required not only the intervention of from a high ranking government official - the Sous-Préfet - but even the leverage from his superior for him to do so. The Sous-Préfet demonstrated developed skills for walking on a razor's edge. On the one hand, he owes it to the party and his superior (as well as to himself) to take action at their request. His endurance and promotion chances lie in the hands of the CDS so long as the quotation system works and the CDS is in power. On the other hand, once the 
case falls within the magistrate's jurisdiction, he has no longer formal say in it The comments he had added on the preliminary transcript on the court ruling was therefore not a direct contradiction of the magistrate's decision - only a restriction of it's validity to one year and an announcement of a forthcoming appeal. The Sous-Préfet managed to fashion his intervention in a way in which everybody - the disputing parties, the CDS and the magistrate - knew he was disapproving and suspending the magistrate's decision but still prevented the magistrate from denouncing his actions publicly. As the magistrate explained: "If I took his illegal behavior seriously and denounced it, it would only mean that the people would take it even more seriously and accept it as something important. The legal terms are even misspelled and it is an entire nonsense". The magistrate might be right that open contestation of the Sous-Préfet's behavior would merely endow it with more importance, but on the other hand, ignoring it did not make it undone either.

The intervention by the Sous-Préfet could turn out to be successful, since the case is now pending and the magistrate is transferred to another district and being replaced by a new magistrate who might review the case differently considering the plausibility of both litigants' versions.

Room for manoeuvre for the Sous-Préfet

39 A dispute had occurred over a cattle corridor in a village in the Canton of Gao. Omar and a group of villagers neighboring a cattle corridor had objected to the use of the corridor by the cattle of Saley and another group of villagers. While Omar would concede to let the corridor be used by people bringing their cattle to the market, since the cattle would be guarded by the adult person wanting to sell it, and be few in numbers, he resisted that the corridor was used for the villagers' cattle to reach a small pasture, since they would then only be herded by young boys and be more numerous and thus cause more crop damage.

When Omar had prohibited Saley from passing, Saley had contacted the Sous-Préfecture in order to complain about it The Sous-Préfet went out to the village assisted by the Chef de Service de l'Environnement who also happened to be the permanent secretary of the tenure commission. They were accompanied by two Gardes Républicains. A meeting was held in the village and resulted in Omar accepting Saley's use of the corridor. The Sous-Préfet declared that the sanctity of the corridor was henceforth protected by the Coran, and the settlement was taken down in writing.

41 Two weeks later, Omar and his neighbors begun to extend their fields and plant their crops in the corridor thus annihilating it, and the dispute erupted again. Saley notified the Sous-Préfet who sent out a team consisting of the Assistant Sous-Préfet and the Chef de Service de l'Environnement and had them accompanied by two Gardes Républicains. The Sous-Préfet instructed them to arrest and bring back to Mariga anyone who disregarded the earlier settlement

42 At the village a heated debate ensued and went on for about one hour with the occasional intervention from the two guards separating the most agitated hot heads with the rifle butts. Eventually, it was established that Omar and neighbors had indeed planted in the corridor, and Omar had furthermore issued a Coranic curse on Saley if he would once again make use of the corridor. The Assistant Sous-Préfet and the Chef de Service de l'Environnement demanded that the earlier decision was respected, and Omar and neighbors finally conceded to respect the corridor. But Omar would not cancel his curse. Unable to reach a settlement and convincingly undo the curse and 
unwilling to arrest half of the male population in the village, the Assistant Sous-Préfet and the Chef de Service de l'Environnement scheduled a new hearing in Mariga for the coming Friday ; three days away.

Come Friday, two groups of about 20 men came from the village to the hearing. Between Tuesday and Friday, however, a delegation from the village representing Omar Moussa had made contact with the Sous-Préfet one night at his home with the Canton chief's representative as an intermediary. On Friday, before the hearing, an ordinary meeting of the tenure commission was held at the Sous-Préfecture. The Sous-Préfet used the occasion to state that he intended to conduct the hearing himself. This was taken as a cue by both the Assistant Sous-Préfet and the Chef de Service de l'Environnement not to attend which, therefore, they did note After the meeting, the Sous-Préfet gathered the two groups from the village in the square of the Sous-Préfecture and declared that while the cattle corridor had once been respected as such, it was never a proper corridor. Therefore Omar and his neighbors could rightfully extend their fields into the corridor and cancel it. And if anyone let his animals stray on the former corridor, it would be considered illegal crop damage. The Sous-Préfet reminded the two groups that Saley had used the Coran to protect his fields, and he expected all good muslims to respect that. He then closed the meeting and sent people home. Saley later made contact with the CDS polit bureau and the dispute continued.

While the tenure commission, including the Sous-Préfet, his assistant and the Chef de Service de l'Environnement, had once settled the affair in favor of protection of the cattle corridor and the free use of it, the Sous-Préfet undid this decision and settled the case most differently. When asked about this, neither the Assistant Sous-Préfet and the Chef de Service de l'Environnement would state a clear reason but concurrently and independently suggested that the Sous-Préfet bad stepped out of his function as a member and president of the tenure commission and had assumed his role as the Sous-Préfet. Overruling the tenure commission's decision from this position would not be questioned although the Sous-Préfet was not fonnally entitled to do 80 . While being colleagues on equal terms in the tenure commission, the Chef de Service de l'Environnement did not feel capable of challenging the Sous-Préfet, who in other matters is his superior, and he preferred to ignore the incident. The Assistant Sous-Préfet, being the immediate subordinate of the Sous-Préfet, was even less inclined to question the validity of the new decision. The Sous-Préfet himself denied that it had ever happened.

Exploring the paradoxes

As the cases indicate, a number of paradoxes seem to emerge from the recent Nigerien experience. The CDS has so far experienced considerable political progress, but it seems that the party has begun to be caught up by its own success. The political actions of challenging the state and the traditional chiefs by mounting pressure and erecting parallel fora of justice were once valiant guerilla tactics. Since the state was run by an unconstitutional party created and controlled by the military, political sabotage had a kind of Robin Hood-legitimacy to it. Although the AMACA/CDS interference with the administration of justice was often as arbitrary as the administration's operation itself, it was seen as committed efforts to redress injustice.

Later, however, the same tactics have different connotations. When the CDS occupied the presidency of the republic and was a major partner in the coalition government, it must abide by the constitution and thus had to recognize the separation of the 
legislative, executive and judiciary state powers in order not to become a replica of the old regime. Paradoxically, the rules and logics of democracy seem to counteract this : elected into office parties and politicians are there for one term at the time. In order to become reelected one has to deliver some political results, but the economic quagmire into which Niger is sinking makes it an impossible task for any government to deliver much tangible economic and social progress within one election term. Therefore it is tempting to stay put on the old hunting ground for popular support and satisfy the electorate through redressing injustice.

It is often argued that rights in land in African societies most often are claimed by virtue of membership or status in various social groups and that these claims are renegotiated in the process of changing political relations and social identities. Viewed from this angle, democracy has not changed access-rules to land much; CDS merely erected itself as a "political tribe" in opposition to the former political power -MNSD. "Membership" of the CDS became important for claims in land and this was rapidly recognized by the electorate. By first appearance, the support for CDS in the rural areas seemed overwhelming, but when probing for reasons for the adherence to the party, the current answer was that it is wise to back a winner, and when questioning the difference between the CDS and the MNSD, the standard answer was: "CDS has the power now". It does, however, not confer legitimacy upon the legal system itself or CDS as its prime governor. The alternative avenues to justice are not abandoned; the Sous-Préfet, the Canton chief and the magistrate are still addressed for complaints or appeals, and the litigants shop for the most promising legal forum for a favorable settlement. In this sense, the CDS-option had simply widened this range of options.

However, it is one thing that people did not go to the CDS because they considered it a legitimate state institution capable of exercising justice, but because the party was considered the opportune avenue for the specific situation, it is another thing if the party itself was promoting state legitimacy or not; increasing the number of legal avenues does not in itself wear on the state's legitimacy. However, since the underlying raison d'être for the CDS was to redress injustice, revoking earlier decisions by other institutions was an important exercise of justification. Furthermore, this reflected neither a consensus about the rules of law or consensus about the authority exercising it since different norms had been applied and all other legal institutions had, with more or less success, been tried overruled by the CDS. The operations must therefore be interpreted as not conducive for endowing the state legal institutions with increasing legitimacy. Rather, it seems as if the modus operandus contributed to its erosion. While conscious about this, the party cadres in Mariga and Zinder had difficulties in avoiding it for two reasons. First, while the CDS had won the elections, the corrupt behavior of chiefs and administrators, which CDS campaigned against, had not disappeared, and it was tempting to use a new favorable position to redress injustice by overruling formally responsible institutions. Second, refraining from intervention would have invited somebody else to do it.

49 Another paradox is rooted in the way that democratization had replaced the one-party command over the administration with a manifest competition over the executive - and thereby the judiciary - between the party politicians and the party appointed civil servants viz. the Sous-Préfet. Since the governing party no longer had complete control over the administration but also had a constitution to respect, the Sous-Préfets could now manoeuvre between two masters - the constitution and their party. The local party 
cadres like Yaccouba Mato and Zakari Ousseini claimed that they have a legitimate right to control and oversee the operations of the local administrator who traditionally had transgressed the limits of his formal attributions extensively. They even competed to be the more zealous umpire. The Sous-Préfet, on the other hand, claimed that while he is a neutral instance, CDS involvement and control was undue politicization. The paradox is that while democratization had loosened the ruling political party's grip on the administration and the Sous-Préfet, the failure to submit him to control from a new democratic institution released his powers, and a new ambiguous dimension of legal procedures had come about.

While this apparently is competition between CDS and the administration, the controversy actually went on within the party due to the Sous-Préfet's party political nomination. A remarkable feature of the party interventions had so far been the absence of bribes. The return for intervention was popularity and office in the state. A position from where spoils are easily controlled by the issuing of public contracts, offering of employment and through embezzlement.

51 Tangible gifts had, nevertheless, so far more taken the reverse course ; candidates from the CDS distributed gifts in order to secure political support. A person like the MP Yaccouba Mato had thus bought 30 bars of sea salt for 75.000 FCFA, and distributed it in some 25 villages among the local CDS leaders to secure their support for the forthcoming nomination of party candidates for parliamentary elections. Others have had boubous (traditional menswear) tailored and distributed like the Sultan does when catering for his followers among the traditional chiefs. The Sous-Préfet, on the other hand, had attempted to buy away Yaccouba Mato's supporters from under him with small public contracts and food aid in order to prepare the ground for another less interfering candidate.

The quest for the loyalty of the lower echelons of the party is a quest for two trophies : One is the image with the local population of the powerful person who can get things done and, perhaps in particular, undone, and thus become the one whom they address. The other is the image with the superior party cadres as the one able to mobilize the electorate.

Since the reassertion of power for both the Sous-Préfet and the local CDS cadres or politicians in general rested considerably upon their active intervention and delivery of "justice", the bitter irony is that whether one or the other will prove to be the most powerful local actor, it will tend to be at the expense of the legitimacy of the state - in particular within the local legal domain.

third paradox worth noting pertains to the use of religious legitimation of rights and truth of statements. In a polycentric legal system marked by institutional competition, it can seem comforting that at least one set of norms prevails for all engaged institutions. However, it becomes somewhat less of a comfort for the seekers of order, when the contextual employment of religious legitimation is explored.

There can be little doubt that the Coran and the Faith as such are highly respected in Nigerien society and that the fear of committing perjury while under a religious oath is sincere for most This is an important reason for the frequent resort to the Coran in conflicts over scarce resources. It is effective. However, the force of a Coranic protection, a Coranic curse or a Coranic oath seem to be at least partly conditioned on another authority. The litigant wanting to take a Coranic oath generally requests a 
political authority for the licence to do so. It is thus in the hands of the Canton chief, the Sous-Préfet, the magistrate or another political authority to sanction the employment of this instrument for imbuing a decision with religious legitimacy. In case 1 of the Settlement, it was thus Zakari Ousseini's presence which inflated Saley's Coranic oath with potency and authority.

On the other hand, if someone as Omar from case 3 boldly transgresses the limits of his own prerogatives and actually issues an "un-authorized" Coranic curse, intermediary political authorities like the Assistant Sous-Préfet and the Chef de Service de l'Environnement were not capable of simply neutralizing it, but had to confer the case to the Sous-Préfet. The fact that the Sous-Préfet did not cancel Omar's curse but used it to encourage all to be "good muslims" and respect it, does not mean that he could not de-fuse a curse or back changing statements with his authority - thus, he actually undid his own earlier Coranic protection of the cattle corridor in his final statement. Rather, it suggests that the religious rationality interacts with an opportunistic immediate purpose rationality making up a disenchanted composite and ambivalent rationality. In the political institutions' competition over jurisdictions the religious discourse therefore make up important terrain and tradition an important modem strategy.

It is evident that the number of tenure disputes which have surfaced in the rural areas in Niger has soared since the downfall of military role. It would be tempting to argue that while the military regime had been capable of enforcing tenurial rules, the democratic regime has been capable of producing nothing but disorder and conflict. Continuing this line of argument, one could hypothesize that the Rural Code would have had better chances of smooth implementation under the Kountché-regime than now under turbulent fumbling democracy. Such a hypothesis is of course futile, and it is also at best only partly true. While tenure disputes were fairly successfully held down by the military government, they were only held down - they were neither solved definitively or made not to have ever happened, as was vainly hoped. It could be asked whether the military government would have conducted the tenure negotiation processes in a way which was not reversed at the eventual conclusion of their rule.

By way of conclusion

The incongruity between the ideal claims to legitimacy and the actual motives for submission to state and party institutions is not reserved for the Nigerien experience, rather it could be argued that it is a general schism of any state.

Berry argues that negotiability of rules and relationships is one of the fundamental characteristics of African societies. (Berry 1993) Indeed, the cases presented above seem to conl1rm her statement. I think, however, it could be successfully argued that negotiability is what characterizes any society; the form of negotiation is what distinguishes them. When democracy was introduced through a constitution as the new legitimate form of social negotiation, it seems to have suffered from the impossible modem ambition of state building; that society must henceforth be conducted within the framework of democracy rather than the opposite; that democracy was inserted into society with already existing forms of negotiation. This seems to have affected the other ambitious modernization effort : the Rural Code.

While the Rural Code has been an effort to modernize the land tenure system by formalizing rights in land through local negotiations and tenure commissions and thereby increase tenure security, politization and competition between the involved institutions has led to increasing insecurity: not only does democracy question the 
authority of the traditional institutions, but the intense political competition engenders unpredictability at a higher pace. The embryonic modernity permeating the area of legal procedures in land questions in Niger is thus not one of disenchanted rational predictability as foretold by Weber, but one of disenchanted composite rational unpredictability.

61 As a piece of social engineering the Rural Code seems still to be some considerable way from the desired outcome. It has, however, in conjuncture with the advent of democracy released new social processes which could transform the rural society quite substantially.

\section{BIBLIOGRAPHY}

Berry, Sara (1993) : No Condition is Permanent - the Social Dynamics of Agrarian Change sub-Saharian Africa, University of Wisconsin Press, Madison, $258 \mathrm{p}$.

Comité National du Code Rural / Ministère de l'Agriculture et de l'Elevage / République du Niger (1993) : Principes d'orientation du Code Rural (Ordonnance n 93-015 du 2 mars) 28 p.

Jessop, Bob (1990) : State Theory - Putting Capitalist States in Their Place, Polit y Press, Cambridge. $413 \mathrm{p}$.

Moore, Sally Falk (1978) : Law as Process, Routledge \& Kegan Paul, London. 270 p.

Moore, Sally Falk (1988) : "Legitimation as a process - the expansion of government and party in Tanzania" in : Cohen, R. \& J.D. Toland (eds.) : State Formation and Political Legitimacy, Transaction Books, New Brunswick. pp. 155-72.

Ngaido, Tidiane (1994) : La mise en place du Code Rural-Perceptions et attentes du monde rural nigérien, LTC avec USAID-Niger, Document de Travail $\mathrm{n}^{\circ}$ 7, Niamey, $39 \mathrm{p}$.

Ngaido, Tidiane (1993) : Land Use Conflicts in the Rural Areas of Niger - the Case of Kollo Arrondissement, LTC with USAID-Niger, Discussion Paper $n^{\circ} 1.30$ p.

\section{NOTES}

1.The tenure commission is composed of the Sous-Préfet who presides over it ; the Secrétaire Permanent du Code Rural (in the case of Mariga the Chef de Service de l'Environnement), the heads of the local ministerial departments concerned with rural development, the traditional chiefs concerned and representatives of the farmers', the herders', the women's and the youth organizations. The commission is supposed to conciliate in tenure disputes and oversee the establishment of the "dossier rural" for a piece of land - the transitional tenurial stage leading 10 private property (Comité National du Code Rural 1993 : art 1 and 116-21).

2.The state is conceptualized as a complex institutional ensemble in which one should not expect to find a unitary, unified, coherent agency, but one where various potential 
structural powers are inscribed in the institutions. (See Moore $1978: 18,56$; Jessop $1990: 365-67)$.

3.All names and locations below the Department level are pseudonyms.

AUTHOR

\section{CHRISTIAN LUND}

Roskilde University, Denmark. 